\title{
Analisis Finansial Sistim Penggemukan Sapi Potong oleh Perusahaan dan Peternakan Rakyat di Kabupaten Kupang
}

\author{
E. Edi Sunarto ${ }^{\mathrm{a}}$, Obed H. Nono ${ }^{\mathrm{a}}$, Ulrikus R. Lole ${ }^{\mathrm{a}}$, dan Hilarius Yosef Sikone ${ }^{\mathrm{b}}$ \\ a. Fakultas Peternakan, Universitas Nusa Cendana, Kupang, NTT, 85228, Indonesia \\ b. Fakultas Pertanian, Universitas Timor, Kefamenanu, TTU - NTT, 85613, Indonesia
}

\section{Article Info}

\section{Article history:}

Received 11 Agustus 2016

Received in revised form 18 September 2016

Accepted 21 September 2016

Keywords:

Ternak Sapi Potong

Analisis Finansial

Pendapatan Peternak

\begin{abstract}
Abstrak
Tujuan dari penelitian ini untuk menganalisis pendapatan usaha penggemukan sapi di perusahaan peternakan dan peternakan rakyat, kelayakan usaha penggemukan sapi potong di perusahaan peternakan dibandingkan dengan usaha penggemukan sapi potong di peternakan rakyat, dan faktor-faktor yang mempengaruhi besaran pendapatan dari usaha penggemukan sapi potong di perusahaan dan peternak. Metode yang digunakan dalam penelitian ini adalah metode survey. Pengambilan wilayah sampel ditentukan secara Sampel Acak Klaster (Cluster Random Sampling) dan responden secara purposive sampling dengan jumlah responden sebanyak 60 responden. Analisis kelayakan finansial dikaji secara kuantitatif melalui analisis biaya dan manfaat, analisis laba rugi, analisis kriteria investasi, yaitu meliputi Net Present Value (NPV), Internal Rate Return (IRR), Net Benefit Cost Ratio (Net B/C), Payback Pariod (PP), dan Analisis Switching Value. Hasil analisis menunjukan bahwa usaha penggemukan di perusahaan peternakan untuk sapi jantan memiliki nilai NPV sebesar Rp. 7.472.015.043; B/C sebesar 3.09; IRR sebesar 30.15\%; Usaha penggemukan sapi betina afkir memiliki nilai NPV sebesar Rp. 3.720.704.516,- B/C sebesar 4.87; IRR sebesar 34\%; sementara usaha penggemukan sapi jantan di peternakan rakyat memiliki nilai NPV sebesar Rp. 61.825.470; B/C adalah 4.92; IRR sebesar 95\%. Faktor-faktor yang mempengaruhi besaran pendapatan untu usaha penggemukan sapi adalah jumlah ternak, harga bakalan, tenaga kerja dan harga jual, biaya pakan, dan bobot akhir ternak. Kesimpulan yang diperoleh dari penelitian ini adalah usaha penggemukan sapi potong di Kabupaten Kupang baik yang dilakukan oleh peternak maupun perusahaan peternakan layak dijalankan. (O2016 dipublikasikan oleh JAS.
\end{abstract}

\section{Pendahuluan}

Pengembangan ternak sapi potong yang digalakan oleh pemerintah dengan mencanangkan program swasembada daging pada tahun 2014 bertujuan untuk meningkatkan produktivitas ternak sapi potong sehingga dapat bersaing dengan sapi impor dan Provinsi NTT merupakan salah satu provinsi yang diarahkan untuk pengembangan peternakan melalui plasma nutfah dan penggunaan teknologi peternakan.

Populasi ternak sapi di Provinsi Nusa Tenggara Timur (NTT) pada tahun 2011 sebesar 778.633 ekor, pada tahun 2012 meningkat menjadi 814.482 ekor $(4,60 \%)$ dan pada tahun 2013 meningkat sebesar 823.135 ekor (1,06\%) (Dinas Peternakan NTT, 2013). Dengan demikian dari aspek jumlah populasi terjadi peningkatan populasi ternak sapi sebesar $3,54 \%$ pada tahun 2013. Walau demikian dari aspek mutu genetik mengalami penurunan. Penurunan in disebabkan karena rendahnya produktivitas ternak sapi di samping faktor lingkungan, tingginya pemotongan betina produktif dan tingginya kematian ternak muda (Bamualim and Wirdahayati, 2003).

Rendahnya produktivitas ternak berdampak pada rendahnya produksi daging yang dihasilkan per ekor sehingga untuk memenuhi kebutuhan daging nasional maupun lokal dibutuhkan lebih banyak ternak. Hal ini berdampak pada tingginya pemotongan ternak betina produktif sehingga menyebabkan penurunan populasi dan produktivitas ternak sapi di provinsi NTT. Selain itu, tingkat pemotongan ternak betina telah melebihi jumlah dan laju penggantian induk (replacement rate). Dengan demikian, akan terjadi pengurasan ternak sapi yang berdampak pada penurunan populasi di NTT. Guna mengatas masalah rendahnya produksi daging, berbagai upaya telah dilakukan untuk meningkatan produktivitas ternak, antara lain melalui penggemukan ternak sapi baik itu sapi jantan maupun sapi betina afkir (Jelantik, 2006).

\section{Metode}

Penelitian ini dilaksanakan di kabupaten Kupang selama 2 bulan, menggunakan metode survey (survey method) yaitu suatu metode penggumpulan data dari sejumlah unit atau individu dalam jangka waktu yang bersamaan dengan menggunakan beberapa daftar pertanyaan (koesioner). Penentuan lokasi penelitian dilakukan secara sample acak klaster (klaster random sampling) sehingga diperoleh 3 (tiga) kecamatan yaitu kecamatan Amarasi Timur, Amarasi Barat dan Amarasi. Tiap kecamatan dilakukan pengambilan sample secara sengaja (purposive sampling) sehingga dipilih 1 kelompok yang melakukan kegiatan penggemukan sapi dan tiap kelompok terdiri dari 20 orang anggota kelompok, sehingga jumlah sampelnya adalah 60 responden.

Data berasal dari data primer dan sekunder yang diolah dengan menggunakan analisis statistik. Analisis kelayakan finansial dikaji secara kuantitatif melalui analisis biaya dan manfaat, analisis laba rugi, analisis kriteria investasi, yaitu meliputi Net Present Value (NPV), Internal Rate Return (IRR), Net Benefit Cost Ratio (Net B/C Ratio), Payback period (Gittinger, 2008).

Analisis faktor-faktor yang mempengaruhi pendapatan usaha ternak sapi potong digunakan analisis Regresi Linear Berganda untuk mengukur pengaruh variabel prediktor (variabel bebas) terhadap variabel terikat. Secara matematis dirumuskan: $\mathrm{Y}=\mathrm{a}+\mathrm{b} 1 \mathrm{X}_{1}+\mathrm{b} 2 \mathrm{X}_{2}+\ldots+\mathrm{bnXn}$

Keterangan :

$\begin{array}{ll}\mathrm{Y} & =\text { Pendapatan } \\ \mathrm{A} & =\text { Konstanta } \\ \mathrm{b} 1, \mathrm{~b} 2 \ldots \mathrm{bn} & =\text { Koefisien regresi } \\ \mathrm{X}_{1} & =\text { Umur bakalan ternak sapi } \\ \mathrm{X}_{2} & =\text { Jumlah ternak yang digemukan }\end{array}$

$\begin{array}{ll}\mathrm{X}_{3} & =\text { Harga bakalan } \\ \mathrm{X}_{4} & =\text { Lama pemeliharaan/pengemukan } \\ \mathrm{X}_{5} & =\text { Curahan jam kerja } \\ \mathrm{X}_{6} & =\text { Jumlah pemberian pakan }\end{array}$

3. Hasil dan Pembahasan

3.1 Analisis Kelayakan Finansial Penggemukan Sapi Jantan Peternakan Rakyat

Umur responden di 3 Kecamatan yang paling banyak adalah kisaran 46-60 tahun yaitu sebanyak 21 responden atau $35 \%$ dari jumlah responden. Rata-rata umur responden dalam penelitian ini digolongkan dalam usia produktif atau usia kerja. Usia produktif akan lebih optimal dalam penggelolaan usaha peternakan dan lebih cepat menyerap dan mengikuti teknologi terapan.

Jumlah responden yang memiliki pengalaman paling banyak yaitu diatas 20 tahun sebanyak 26 orang atau $43,33 \%$. Pengalaman beternak yang tinggi mampu memberikan pengetahuan, kemampuan dan keahliannya dalam rangka mengembangkan usaha perternakan dan peningkatan pendapatan peternak itu sendiri. Pengalaman beternak akan mempengaruhi hasil akhir dari usaha beternak.

Berdasakan hasil penelitian, rata-rata jumlah kepemilikan ternak sapi potong untuk penggemukan sebanyak $9.7 \mathrm{UT} / \mathrm{responden}$ dan luas lahan yang dimiliki responden sebesar 7,38 Ha. Ini berarti setiap $1 \mathrm{Ha}$ lahan yang dimiliki responden dimanfaatkan untuk melakukan usaha penggemukan sapi sebanyak 1,3 UT. Bila dipadukan antara kepemilikan ternak dan luas lahan yang dikuasai responden maka daya tampung lahan yang dimiliki untuk memelihara ternak sapi potong mampu menampung ternak yang jumlahnya lebih banyak lagi. Kegiatan pertanian dan peternakan merupakan satu kegiatan yang umumnya dilakukan petani untuk bisa mengoptimalkan pendapatan dengan pemanfaatan sumberdaya alam yang ada dan mengurangi kegagalan (resiko) dalam berusahatani, sekaligus dapat meningkatkan pendapatan keluarga.

Tabel 1. Kondisi Ekonomi Rumah tangga Peternak Sapi Potong Penggemukan pada Peternakan Rakya

\begin{tabular}{llr}
\hline \multicolumn{1}{c}{ Item } & \multicolumn{1}{c}{$\begin{array}{c}\text { Peternakan } \\
\text { rakyat }\end{array}$} & $\begin{array}{r}\text { Persentase } \\
(\%)\end{array}$ \\
\hline Pendapatan & & \\
Usaha Ternak Sapi Potong (Rp/thn/responden) & $10,626,667$ & 44,15 \\
Usaha Lahan Kebun (Rp/thn/responden) & $6,600,000$ & 27,42 \\
Usaha Lain (Rp/thn/responden) & $6,845,000$ & 20,44 \\
Jumlah & $24,071,667$ & 100 \\
\hline Pun
\end{tabular}

Pengeluaran

a. Konsumsi Non Pangan (Rp/thn/responden) $\quad 4,587,000$

b. Konsumsi Pokok Pangan (Rp/thn/responden) $582,200,000$

c. Investasi (Rp/thn/responden) $\quad 4,761,290$

Jumlah $\quad 32,190,000$

Pendapatan rumahtangga peternak sapi potong bersumber dari pendapatan usahatani dan pendapatan non usahatani. Pendapatan yang berasal dari usahatani terdiri dari usaha ternak sapi potong dan usaha pertanian/perkebunan (tanaman tahunan). Pendapatan non usahatani meliputi buruh bangunan, buruh tani, dagang dan jasa. Tabel 1 menunjukkan bahwa pendapatan usaha ternak sapi potong pola penggemukan adalah Rp. 10,626,667,-/tahun/peternak dengan besaran kontribusi sebesar $44,15 \%$ dari total pendapatan rumah tangga. Besaran kontribusi usaha ternak sapi potong terhadap pendapatan menggambarkan bahwa fungsi ternak sapi potong pada pola penggemukan di tingkat peternakan rakyat merupakan suatu bentuk usaha. 
Tabel 2. Analisis Kelayakan Finansial Ternak Sapi Bali Jantan Pada Tingkat Peternakan Rakyat

\begin{tabular}{lr}
\hline & Uraian \\
\hline NPV & Nilai \\
IRR & 7.493 .671 \\
B/C & $25 \%$ \\
PP & 1.84 \\
\hline
\end{tabular}

Dari Tabel 2 dapat dilihat bahwa kelayakan secara finansial usaha ternak sapi peternakan rakyat dapat diketahui melalui kriteria NPV, Net B/C dan IRR serta PBP. Nilai bersih sekarang (NPV) yang ada pada tingkat suku bunga $12 \%$ yaitu sebesar Rp.7.493.671,-. Nilai NPV tersebut positif berarti usaha tersebut layak secara finansial.

Net B/C digunakan untuk mengukur berapa kali lipat benefit (manfaat) yang diperoleh dari cost (biaya) yang dikeluarkan selama berjalannya usaha Nilai Net B/C ratio sebesar 1,84 yang menggambarkan bahwa setiap penambahan biaya sebesar Rp1000 akan diperoleh manfaat bersih sebesar Rp1840. Nilai Net B/C ini lebih besar dari satu yang berarti dari sudut kriteria ini usaha ternak sapi peternakan rakyat secara finansial layak.

Sementara itu nilai IRR yang diperoleh sebesar $25 \%$ yang menggambarkan bahwa pada tingkat suku bunga tersebut nilai manfaat yang diterima sama dengan nilai biaya yang dikeluarkan. Dengan perkataan lain pada tingkat suku bunga $25 \%$, NPV $=0$. Berdasarkan kriteria ini usaha ternak sapi peternakan rakyat layak secara finansial. Usaha ini menjadi tidak layak apabila tingkat suku bunga bank bergerak melampaui $25 \%$.

Pada Tabel 3 terlihat bahwa, besarnya NPV yang diterima peternakan rakyat adalah Rp 4.477.071 dengan nilai Net B/C sebesar 1,65 dan IRR sebesar $19 \%$ sesuai dengan discount rate yang digunakan. Jika dibandingkan besaran persentase maksimum antara penurunan volume penjualan sapi siap potong dan peningkatan biaya variabel, besaran persentase maksimum penurunan volume penjualan sapi siap potong lebih rendah dibandingkan besaran persentase maksimum peningkatan biaya variabel. Dengan demikian dapat dikatakan bahwa pada usaha penggemukan sapi potong baik jantan maupun betina pada tingkat peternakan rakyat komponen penjualan sapi siap potong lebih peka terhadap perubahan dibandingkan dengan biaya variabel. Komponen yang lebih peka terhadap perubahan tersebut hendaknya lebih diperhatikan oleh pihak manajemen sehingga perubahan yang terjadi tidak melebihi batasan yang ada, karena jika melebihi batasan yang ada, maka usaha yang dijalankan akan mengalami kerugian dan usaha tidak lagi dinyatakan layak untuk dijalankan.

Tabel 3. Analisis Sensitivitas pada Peternakan Rakyat dengan Kenaikan Biaya Produksi Variabel 25\% dan Penurunan Pendapatan Sebesar 20\%

\begin{tabular}{lcccccc}
\hline \multirow{2}{*}{ Uraian } & \multicolumn{7}{c}{ Sensitivitas } \\
\cline { 2 - 7 } & $\begin{array}{c}\text { Biaya } \\
\text { Variabel }\end{array}$ & Pendapatan & NVP (14\%) & $\begin{array}{c}\text { IRR } \\
(\%)\end{array}$ & B/C & PP \\
\hline $\begin{array}{l}\text { Peternakan } \\
\text { Rakyat }\end{array}$ & Naik 25\% & Turun 20\% & 4.477 .071 & 19 & 1.65 & 3,3 \\
\hline
\end{tabular}

\subsection{Analisis Kelayakan Finansial Penggemukan Sapi Jantan pada PT}

\section{Bumi Tirta}

Dalam rangka membuka usaha penggemukan sapi jantan PT Bumi Tirta maka diperlukan sejumlah modal yaitu modal investasi dan modal operasional. Di pihak lain modal kerja atau modal operasional untuk usaha penggemukan sapi meliputi biaya pengadaan bakalan, biaya pakan konsentrat, biaya tenaga kerja, biaya obat-obatan, biaya overhead (bahan bakar, listrik, air dan telepon).

Perhitungan biaya investasi dan biaya operasional untuk usaha penggemukan sapi Bali dilakukan dengan menggunakan beberapa asums sebagai berikut:

a. Populasi awal bulan pertama dalam tahun pertama 50 ekor (pejantan bakalan)

b. Peningkatan belanja bakalan $2 \%$ dari populasi awal dilakukan bulan ke-2 sampai bulan ke-7

c. Pengurangan belanja bakalan $30 \%$ pada bulan ke-8 sampai bulan ke 12 dengan pertimbangan ketersediaan pakan.

d. Total populasi awal tahun pertama 481 ekor (pejantan bakalan 481 ekor)

e. Pada tahun pertama total penjualan sapi gemukan siap potong sebanyak 372 ekor.

f. Jumlah penjulan sapi gemukan siap potong bertambah setiap tahunnya sesuai peningkatan populasi bakalan yang digemukan..

g. Mortalitas $2 \%$

h. Pemeliharaan dengan sistem dikandangkan selama 5 bulan (150 hari).

i. Harga sapi pejantan bakalan Bali Rp 5,039,326 /ekor.

j. Harga jual sapi gemukan siap potong tahun rata-rata Rp.9,945,000 /ekor.

k. Kebutuhan pakan per ekor adalah $5 \mathrm{Kg} \mathrm{Bk} /$ hari dengan harga sebesar $\mathrm{Rp}$ $2000 / \mathrm{kg}$.

1. Kebutuhan obat-obatan, vitamin dan mineral $\mathrm{Rp} 20,000$ /ekor/tahun

m. Biaya pupuk per karung sebesar Rp 2,500.

Analisis aspek finansial digunakan untuk menganalisis kelayakan suatu atau dari segi keuangan/finansial dilakukan dengan menggunakan kriteriakriteria penilaian investasi yaitu NPV, IRR, Net B/C, dan Payback Period. Untuk menganalisis dengan empat kriteria tersebut, digunakan arus kas (cash flow) untuk mengetahui besarnya manfaat yang diterima dan biaya yang dikeluarkan oleh PT Bumi Tirta selama penggemukan.

Penerimaan adalah segala sesuatu yang dapat meningkatkan pendapatan sebuah proyek. Arus manfaat pada usaha ini adalah penerimaan dari hasil penjualan sapi potong, pupuk kandang dan nilai sisa.

\section{a. Penerimaan Penjualan Sapi Potong}

Sapi potong dijual dalam bobot kilogram, Rincian proyeksi penjualan sapi potong dapat dilihat pada Tabel 4. Bobot sapi pada saat panen yaitu berkisar 255 kg/ekor, dengan harga jual Rp 39000/kg bobot hidup pada PT Bumi Tirta. Adapun rincian penerimaan yang berasal dari penjualan sapi potong dapat dilihat pada Tabel 4

Proyeksi panen berdasarkan atas pembelian bakalan yang dilakukan setiap bulan dimana lamanya waktu penggemukan adalah 150 hari atau 5 bulan. Dari hasil proyeksi panen di atas maka selanjutnya dikonversi menjadi satuan rupiah Hasil proyeksi penerimaan sepuluh tahun ke depan menunjukkan bahwa nilai penjualan pada tahun pertama (2013) lebih kecil dibandingkan tahun-tahun berikutnya. Hal ini disebabkan karena pada awal periode usaha, kapasitas produksi belum maksimal. Total penjualan pada tahun 2013 sebesar Rp 3,696,697,412, pada tahun 2014 sebesar $\mathrm{Rp} 4,968,556,934$ dan terus meningkat pada tahun-tahun berikutnya (Tabel 4 ).

\section{b. Penerimaan Penjualan Pupuk Kandang}

Penerimaan penjualan pupuk kandang adalah penerimaan sampingan yang dihasilkan pada usaha penggemukan sapi potong. Pupuk kandang berasal dari kotoran sapi yang dapat digunakan sebagai pupuk untuk tanaman sehingga memiliki nilai ekonomis yang dapat dijual. Harga jual pupuk kandang yaitu $\mathrm{Rp}$ 1000/kg. Setiap ekor sapi menghasilkan pupuk kandang sebanyak $10 \mathrm{Kg} / \mathrm{hari}$. Dengan demikian rata-rata penerimaan yang berasal dari pupuk kandang adalah sebesar Rp. 253,544,075,-

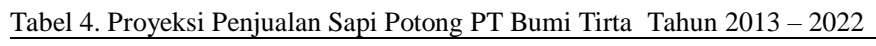

\begin{tabular}{lccrrr}
\hline \multirow{2}{*}{ Tahun } & \multicolumn{4}{c}{ Produksi } & \multicolumn{3}{c}{$\begin{array}{c}\text { Harga jual } \\
(\mathrm{Rp} / \mathrm{kg})\end{array}$} & Penerimaan $(\mathrm{Rp})$ \\
\cline { 2 - 6 } & $($ Ekor $)$ & $\begin{array}{c}\text { Berat Hidup } \\
(\text { Kg/ekor })\end{array}$ & Total $(\mathrm{kg})$ & & \\
\hline 2013 & 372 & 255 & 94,787 & 39,000 & $3,696,697,412$ \\
2014 & 500 & 255 & 127,399 & 39,000 & $4,968,556,934$ \\
2015 & 525 & 255 & 133,769 & 39,000 & $5,216,984,781$ \\
2016 & 551 & 255 & 140,457 & 39,000 & $5,477,834,020$ \\
2017 & 578 & 255 & 147,480 & 39,000 & $5,751,725,721$ \\
2018 & 607 & 255 & 154,854 & 39,000 & $6,039,312,007$ \\
2019 & 638 & 255 & 162,597 & 39,000 & $6,341,277,607$ \\
2020 & 670 & 255 & 170,727 & 39,000 & $6,658,341,488$ \\
2021 & 703 & 255 & 179,263 & 39,000 & $6,991,258,562$ \\
2022 & 738 & 255 & 188,226 & 39,000 & $7,340,821,490$ \\
\hline
\end{tabular}

c. Analisis Kelayakan Finansial Bumi Tirta

Analisis kelayakan finansial digunakan untuk mengukur tingkat kelayakan pendirian PT Bumi Tirta, metode yang digunakan untuk mengukur kelayakan finansial adalah metode penilaian investasi yang meliputi analisis NPV, IRR, Net B/C, serta PP.

Analisis kelayakan ini menggunakan skenario modal sendiri sebesar Rp 1,159,358,000,-. Hasil analisis kelayakan finansial pengusahaan PT Bumi Tirta dapat dilihat pada Tabel 5 .

Tabel 5. Analisis Kelayakan

\begin{tabular}{clc}
\hline No & \multicolumn{1}{c}{ Kriteria Kelayakan } & Hasil Penilaian \\
\hline 1 & NPV & 7.472 .015 .043 \\
2 & Net B/C & 3.09 \\
3 & IRR & $30,15 \%$ \\
4 & PP & 4,27 \\
\hline
\end{tabular}

Berdasarkan Tabel 5, terlihat bahwa hasil NPV pada tingkat diskonto $12 \%$ memiliki nilai positif sebesar Rp. 7.472.015.043. Dengan perkataan lain bahwa NPV yang diperoleh lebih besar dari pada nol. Hal ini menunjukkan bahwa usaha ternak sapi penggemukan yang dilakukan oleh PT Bumi Tirta menurut nilai sekarang menguntungkan untuk dilaksanakan karena memberikan tambahan manfaat sebesar Rp. 150,359,386,--

Nilai Net B/C adalah 3.09 atau lebih besar dari satu. Hal ini menunjukkan bahwa setiap dikeluarkan biaya sebesar Rp. 1000 maka akan diperoleh benefit atau manfaat sebesar Rp. 3.090. Dengan perkataan lain setiap pengeluaran sebesar Rp. 1000 untuk proses produksi penggemukan maka akan diperoleh manfaat bersih atau keuntungan sebesar Rp.2090. Berdasarkan kriteria kelayakan Net B/C, usaha penggemukan sapi yang dilakukan oleh PT Bumi Tirta secara financial layak untuk dilaksanakan.

Selanjutnya Nilai IRR yang diperoleh adalah $30 \%$. Hal ini mengindikasikan bahwa pada tingkat suku bunga tersebut $(30 \%)$ nilai manfaat yang diterima sama dengan nilai biaya yang dikeluarkan. Dengan perkataan lain pada tingkat suku bunga $30 \%, \mathrm{NPV}=0$. Berdasarkan kriteria ini usaha penggemukan sapi oleh PT Bumi Tirta layak secara finansial. Usaha in menjadi tidak layak apabila tingkat suku bunga bank bergerak melampaui $30 \%$. 
d. Analisis Sensitivitas Switching Value (Nilai Pengganti)

Analisis sensitivitas dengan metode penghitungan switching value digunakan untuk mengetahui tingkat perubahan harga output dan biaya sehingga keuntungan mendekati normal dimana NPV sama dengan nol, IRR sama dengan social discount factor dan Net $\mathrm{B} / \mathrm{C}$ sama dengan satu. Analisis sensitivitas dengan metode penghitungan switching value yang dilakukan adalah dengan menghitung perubahan maksimum yang terjadi akibat adanya perubahan beberapa parameter. Parameter yang digunakan yaitu penurunan pendapatan penjualan sapi potong dan peningkatan biaya variabel. Untuk mengetahui resiko mana yang lebih sensitif (peka) terhadap perubahan parameter tersebut, maka perlu dibandingkan analisis sensitivitas dengan metode penghitungan switching value. Hasil analisis sensitivitas dengan metode penghitungan switching value dapat dilihat pada Tabel 6 .

Tabel 6. Analisis Sensitivitas

\begin{tabular}{clc}
\hline No & \multicolumn{1}{c}{ Parameter yang berubah } & Nilai sensitivitas \\
\hline 1 & Peningkatan biaya variabel & $2,5 \%$ \\
2 & Penurunan pendapatan & $3 \%$ \\
\hline
\end{tabular}

Pada Tabel 6 menjelaskan bahwa persentase maximum peningkatan harga biaya variabel yaitu sebesar 2,5 persen. Sedangkan persentase maximum penurunan penerimaan yaitu sebesar 3 persen. Pada perhitungan ini perubahan parameter penurunan penjualan sapi potong lebih sensitif (peka) dibandingkan perubahan parameter peningkatan biaya variabel.

\section{e. Analisis Kelayakan Finansal Penggemukan Sapi Bali Betina Afkir}

Usaha peternakan sapi potong yang dilakukan oleh perusahaan peternakan adalah usaha penggemukan sapi baik itu usaha penggemukan sapi jantan dan juga menjalankan usaha penggemukan sapi betina afkir.

Dalam menjalankan usaha tersebut terdapat komponen biaya produksi yang mesti dikeluarkan oleh perusahan perternakan (Kuntjoro, 2002). Biaya produksi tersebut dibedakan atas biaya tetap dan biaya variabel.

\section{f. Biaya Pembelian ternak}

Pembelian sapi Bali betina afkir adalah pembelian sapi yang dilakukan dengan tujuan untuk di gemukkan. Rata-rata jumlah betina afkir yang digemukkan oleh PT Bumi Tirta adalah 94.52 ekor/tahun, dengan total belanja Rp 374,626,650. Biaya pengadaan betina afkir untuk penggemukan adalah paling besar dibandingkan dengan biaya variabel lain dimana $98.37 \%$ dari total biaya variabel merupakan biaya pengadaan betina afkir.

Hasil analisis menunjukkan bahwa penerimaan dari penggemukan betina afkir yang diterima adalah $\mathrm{Rp} 663.659 .333$ atau Rp7.021.083/ekor. Rata-rata pendapatan yang diperoleh dalam satu tahun usaha adalah $\mathrm{Rp} 281.117 .435$ atau Rp 2.974.083/ekor/tahun. Hal ini menunjukkan bahwa betina afkir memberikan nilai tambah pendapatan yang cukup berarti apabila digemukkan sebelum dijual karena harga yang terbentuk cukup bagus setelah ternak tersebut digemukan selama 3 bulan.

\section{g. Analisis kelayakan finansial penggemukan sapi Bali betina afkir}

Kegiatan investasi penggemukan betina afkir diperlukan modal investasi sebesar Rp. 2,829,858,000. Sementara itu modal operasional yang diperlukan pada tahun pertama sebesar Rp. 6,787,931,296,- dengan rincian biaya produksi

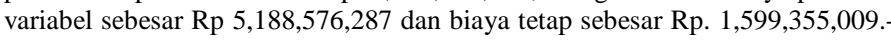
pada usaha penggemukan ini, PT Bumi Tirta menerima keuntungan di tahun pertama usaha.

\section{h. Analisis Arus Kas (Cash Flow) dan Kelayakan Investasi}

Untuk menilai apakah usaha investasi yang ada layak secara finansial, dilakukan analisis dan perhitungan sesuai dengan kriteria kelayakan yang berlaku. Hasil analisis seperti terlihat pada Tabel 7 .

Tabel 7. Kriteria Kelayakan Investasi Usaha Penggemukan Betina Afkir pada PT Bumi Tirta

\begin{tabular}{rlrc}
\hline No. & \multicolumn{1}{c}{ Kriteria kelayakan } & Nilai kriteria & Keputusan \\
\hline 1 & Net Present Value (NPV) (Rp) & Rp. 3,720,704,516.16 & Layak \\
2 & Net B/C & 4.87 & Layak \\
3 & Internal Rate of Return /IRR & $34 \%$ & Layak \\
4 & Payback Period & 3.68 tahun & Layak \\
\hline
\end{tabular}

Dari Tabel 7 dapat dilihat bahwa nilai NPV yang menggambarkan nilai uang yang diterima saat ini sebesar Rp. 3,720,704,516.16 pada discount factor sebesar $12 \%$. Nilai NPV positif berarti usaha tersebut layak secara financial. Nilai Net B/C ratio sebesar 4.87 yang menggambarkan bahwa dengan mengeluarkan biaya sebesar Rp.1000 akan diperoleh manfaat sebesar Rp4.870. Nilai net $\mathrm{B} / \mathrm{C}$ ini lebih besar dari satu yang berarti dari sudut kriteria ini usaha pembibitan sapi secara financial layak. Sementara itu nilai IRR yang diperoleh sebesar 34\% yang menggambarkan bahwa pada tingkat suku bunga 34\% nilai manfaat yang diterima sama dengan nilai biaya yang dikeluarkan. Dengan perkataan lain pada tingkat suku bunga $34 \%, \mathrm{NPV}=0$. Berdasarkan kriteria ini usaha penggemukan betina afkir layak secara finansial. Usaha ini menjadi tidak layak apabila tingkat suku bunga bank bergerak melampaui $34 \%$.

\subsection{Analisis Faktor-Faktor yang Mempengaruhi Pendapatan}

\section{Penggemukan Sapi Jantan di Tingkat Peternak}

Analisis koefisien regresi dengan metode OLS diperoleh koefisien regresi sebagai berikut: $a=-10970000 ; b_{1}=884465,40 ; b_{2}=-8,45 ; b_{3}=-2,688$ dan $b_{4}=$ 7,288 . Dengan demikian pendapatan $(\mathrm{Y})$ dirumuskan dalam persamaan regresi sebagai berikut: $\mathrm{Y}=-10.970 .000+884.465,40 \mathrm{X} 1-8,45 \mathrm{X} 2-2,688 \mathrm{X} 3+7,288 \mathrm{X} 4$

Nilai $b_{1}=884.465,40$ artinya setiap penambahan jumlah ternak sebesar satu satuan maka akan menaikkan pendapatan peternak sebesar 884.465,40 satuan dengan anggapan bahwa faktor lain dianggap tetap (ceteris paribus). Koefisien $b_{2}=-8,45$ berarti setiap kenaikan harga beli bakalan sebesar satu satuan maka akan menurunkan pendapatan peternak sebesar 8,45 satuan dengan anggapan faktor yang lain tetap (ceteris paribus). Keadaan yang sama pula pada biaya tenaga kerja dimana $b_{3}=-2,688$ artinya apabila ada peningkatan biaya tenaga kerja sebesar satu satuan maka akan menurunkan pendapatan petani peternak sebesar 2,688 satuan, ceteris paribus faktor lain. Selanjutnya $b_{4}=7,288$ mengindikasikan bahwa dengan peningkatan harga jual sebesar satu satuan maka akan meningkatkan pendapatan petani peternak sebesar 7,288 satuan dimana faktor lain dianggap tetap (ceteris paribus) (Suranjaya, 2011).

Dengan demikian dapat disimpulkan bahwa faktor-faktor yang berpengaruh nyata terhadap pendapatan usaha peternakan rakyat adalah jumlah ternak, harga bakalan, biaya tenaga kerja dan harga jual.

\section{a. Penggemukan Betina afkir pada PT Bumi Tirta}

Analisis koefisien regresi dengan metode OLS diperoleh koefisien regresi sebagai berikut: $a=-879.437,856 ; b_{1}=-5.150,611 ; b_{2}=-0.956 ; b_{3}=0,081$ dan $\mathrm{b}_{4}=26.384,692$. Dengan demikian pendapatan (Y) dirumuskan dalam persamaan regresi sebagai berikut: $\mathrm{Y}=-879.437,856-5.150,611 \mathrm{X}_{1}-0.956 \mathrm{X}_{2}+$ $0,081 \mathrm{X}_{3}+26.384,692 \mathrm{X}_{4}$

Nilai $b_{1}=-5.150,611$ artinya setiap penambahan jumlah ternak sebesar satu satuan maka akan menurunkan pendapatan peternak sebesar 5150,611 satuan dengan anggapan bahwa faktor lain dianggap tetap (ceteris paribus). Koefisien $b_{2}=-0,956$ berarti setiap kenaikan harga beli betina afkir sebesar satu satuan maka akan menurunkan pendapatan peternak sebesar 0,956 satuan dengan anggapan faktor yang lain tetap (ceteris paribus). Keadaan yang sama pula pada biaya pakan dimana $b_{3}=0,081$ artinya apabila ada peningkatan biaya pakan sebesar satu satuan maka akan meningkatkan pendapatan sebesar 0,081 satuan, ceteris paribus faktor lain. Selanjutnya $b_{4}=26.384,692$ mengindikasikan bahwa dengan peningkatan bobot badan akhir sebesar satu satuan maka akan meningkatkan pendapatan sebesar 26.384,692 satuan dimana faktor lain dianggap tetap (ceteris paribus). Dengan demikian dapat disimpulkan bahwa faktor-faktor yang berpengaruh nyata terhadap pendapatan usaha penggemukan betina afkir adalah jumlah betina afkir, harga beli betina afkir dan bobot badan akhir.

\section{b. Penggemukan Jantan pada PT Bumi Tirta}

Analisis koefisien regresi dengan metode OLS diperoleh koefisien regresi sebagai berikut: $\mathrm{a}=47630000000$; Harga jual $\left(\mathrm{b}_{5}\right)=-4597,037$; biaya pakan $\left(\mathrm{b}_{6}\right)=680,918$; biaya kesehatan $\left(\mathrm{b}_{4}\right)=26,961$ dan biaya kandang $\left(\mathrm{b}_{8}\right)=$ -1404,189. Dengan demikian pendapatan (Y) dirumuskan dalam persamaan regresi sebagai berikut: $\quad \mathrm{Y}=47630000000+26,961 \mathrm{X}_{4}-4597,037 \mathrm{X}_{5}+$ $680,918 \mathrm{X}_{6}-1404,189 \mathrm{X}_{8}$

Nilai $b_{4}=26,961$ artinya setiap penambahan biaya kesehatan sebesar satu satuan maka akan meningkatan pendapatan pengusaha sebesar 26,961 satuan dengan anggapan bahwa faktor lain dianggap tetap (ceteris paribus). Koefisien $b_{5}=-4597,037$ berarti setiap kenaikan harga jual sebesar satu satuan maka akan menurunkan pendapatan peternak sebesar 4597,037 satuan dengan anggapan faktor yang lain tetap (ceteris paribus). Keadaan yang sama pula pada biaya pakan dimana $b_{6}=680,918$ artinya apabila ada peningkatan biaya pakan sebesar satu satuan maka akan meningkatkan pendapatan sebesar 680,918 satuan, ceteris paribus faktor lain. Selanjutnya $b_{8}=-1404,189$ mengindikasikan bahwa dengan peningkatan biaya kandang sebesar satu satuan maka akan menurunkan pendapatan sebesar 1404,189 satuan dimana faktor lain dianggap tetap (ceteris paribus). Dengan demikian dapat disimpulkan bahwa faktor-faktor yang berpengaruh nyata terhadap pendapatan usaha penggemukan jantan pada PT Bumi Tirta adalah harga jual, biaya pakan dan biaya kandang

\section{Simpulan}

Rata-rata pendapatan yang diperoleh pada usaha peternakan rakyat adalah Rp.22.740.313/tahun atau Rp.2.344.362/ekor/tahun sedangkan pada tingkat perusahaan rata-rata pendapatan yang diperoleh dari usaha penggemukan jantan adalah Rp Rp 612,218,595,- atau Rp Rp.1,224,437,-/ekor/tahun.

Faktor-faktor yang berpengaruh nyata terhadap pendapatan usaha peternakan rakyat adalah jumlah ternak, harga bakalan, biaya tenaga kerja dan harga jual. Pada tingkat perusahaan, khusus pada penggemukan sapi jantan faktor yang mempengaruhi pendapatan adalah biaya pakan, biaya kandang dan harga jual sementara pada usaha penggemukan betina afkir, faktor yang berpengaruh terhadap pendapatan adalah jumlah ternak, harga beli dan bobot badan akhir.

Usaha penggemukan ternak sapi potong baik yang dijalankan oleh peternak maupun oleh perusahaan peternakan adalah layak secara financial dimana pada peternakan rakyat diperoleh nilai NPV sebesar Rp.61.825.470; B/C = 4.92 dan IRR $=95 \%$; pada tingkat perusahaan untuk penggemukan sapi sapi jantan 
diperoleh NPV=7.472.015.043; Net $\mathrm{B} / \mathrm{C}=3.09$ dan IRR-30,15\%; sementara untuk ternak betina afkir dieroleh NPV=3.720.704.516; Net B/C=4.87 dan IRR $=34 \%$.

\section{Pustaka}

Bamualim, A., Wirdahayati, R.B., 2003. Nutrition and Management Strategis to Improve Bali Cattle productivity in Nusa Tenggara. ACIAR Proc. No. 110.pp. 17-22.

Dinas Peternakan NTT, 2013. Statistik Peternakan Propinsi NTT.

Gittinger, J.P., 2008. Analisa Proyek-Proyek Pertanian., Edisi Kedua. ed. Universitas Indonesia Press, Jakarta.

Jelantik, I.G.N., 2006. Chemical Composition And Energy Value Of Some Feedstuffs For Ruminants From Nusa Tenggara Timur. Bul. Nutr. vol 9 no. 3 .

Kuntjoro, 2002. Kelayakan Finansial Proyek.

Suranjaya, I.G., 2011. Diskripsi Dan Analisis Faktor-Faktor Produksi Yang Mempengaruhi Pendapatan Peternak Pada Usaha Penggemukan Sapi Bali Berskala Kecil. Maj. Ilm. Peternak. Udayana Bali Vol. 14. Nomor 1. 